\title{
The biology and dynamics of mammalian cortical granules
}

Min Liu

\begin{abstract}
Cortical granules are membrane bound organelles located in the cortex of unfertilized oocytes. Following fertilization, cortical granules undergo exocytosis to release their contents into the perivitelline space. This secretory process, which is calcium dependent and SNARE protein-mediated pathway, is known as the cortical reaction. After exocytosis, the released cortical granule proteins are responsible for blocking polyspermy by modifying the oocytes' extracellular matrices, such as the zona pellucida in mammals. Mammalian cortical granules range in size from 0.2 um to 0.6 um in diameter and different from most other regulatory secretory organelles in that they are not renewed once released. These granules are only synthesized in female germ cells and transform an egg upon sperm entry; therefore, this unique cellular structure has inherent interest for our understanding of the biology of fertilization. Cortical granules are long thought to be static and awaiting in the cortex of unfertilized oocytes to be stimulated undergoing exocytosis upon gamete fusion. Not till recently, the dynamic nature of cortical granules is appreciated and understood. The latest studies of mammalian cortical granules document that this organelle is not only biochemically heterogeneous, but also displays complex distribution during oocyte development. Interestingly, some cortical granules undergo exocytosis prior to fertilization; and a number of granule components function beyond the time of fertilization in regulating embryonic cleavage and preimplantation development, demonstrating their functional significance in fertilization as well as early embryonic development. The following review will present studies that investigate the biology of cortical granules and will also discuss new findings that uncover the dynamic aspect of this organelle in mammals.
\end{abstract}

Keywords: mammalian cortical granules, oocytes, fertilization, exocytosis, SNARE proteins, calcium, cortical granule free domains, pre-fertilization release, heterogeneity

\section{Background}

Mammalian fertilization is a sequence of coordinated events involving multiple steps of mutual recognitions between haploid male and female gametes. In mammals, fertilizable oocytes are ovulated along with the first polar body, as well as the extracellular matrix (ECM) zona pellucid (ZP) which is composed of three glycoproteins, ZP1, ZP2, and ZP3 [1,2] and the cumulus oophorus which is made of several layers of ovarian follicular granulose cells embedded in hyaluronic acid-containing ECM (Figure 1). Passage of a sperm through these semi-permeable investments surrounding an oocyte is absolutely essential in the initiation of fertilization. First, sperm need to pass through the cumulus

Correspondence: Im@faculty.pccu.edu.tw

Department of Life Science and Graduate Institute of Biotechnology, Private Chinese Culture University, Taipei, Republic of China oophorus and they do so by disrupting the macromolecular structure of the matrix [3] and by sperm hyaluronidase activity [4]. Next, formation of a pathway through the ZP is triggered by the recognition of a cognate receptor on sperm and the ZP3 glycoprotein of the oocyte by protein-carbohydrate recognition $[5,6]$, followed by the induction of proteolytic enzyme release from the sperm head termed acrosome reaction. Sperm penetration through the ZP is subsequently facilitated by the binding between acrosome reacted sperm and ZP2 glycoproteins [7]. Most studies of mammalian fertilization support the model described above regarding gamete recognition and interaction; however, a recent report has revealed that ZP3 glycoprotein is not essential and sufficient to induce sperm acrosome reaction while binding to ZP2 is account for sperm-egg recognition during fertilization in mice [8]. Whether this model 


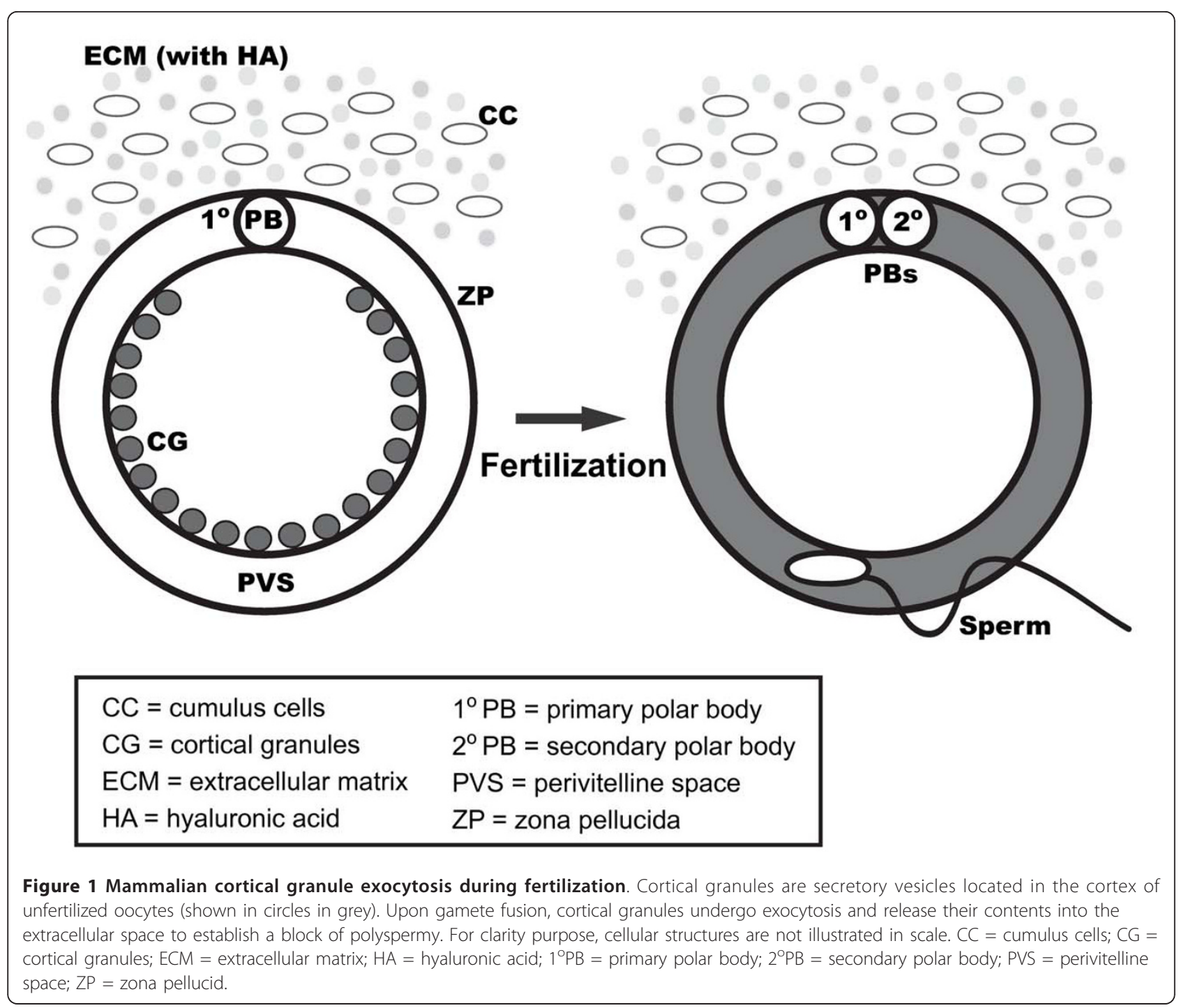

for gamete recognition is adequate for all mammals still needs to be determined experimentally.

Prior to fertilization, a sperm needs to swim through the perivitelline space (PVS) and fuses with the oocyte through a fertilin/integrin- mediated adhesion process [9-15]. Following gamete fusion, the fertilized oocyte resumes meiosis and protrudes the second polar body, which marks the end of fertilization process. However, a successful fertilization is not guaranteed unless preventative mechanism(s) inhibiting fertilization by more than one sperm, a condition known as polyspermy, is established immediately following gamete fusion since polyploidy is fatal to an embryo. Physiological polyspermy or penetration of the oocyte by more than a single sperm occurs in numerous species including insects, reptiles, and birds, while mammalian polyspermic fertilization is considered abnormal, which leads to developmental failure of the zygote and spontaneous abortion in humans.
A recent study of porcine oocytes reveals that pig is a species with a high incidence of polyspermy under physiological conditions or in vitro fertilization [16]. Interestingly, porcine oocyte cytoplasm has the capability to remove the accessory sperm [17] and some poly-pronuclear pig eggs can develop to term if accessory sperm do not interrupt the embryo genome [18], demonstrating that this species depends on unique mechanisms to deal with the occurrence of polyspermy. Nevertheless, a defense against polyspermic fertilization needs to be established rapidly after fertilization under most circumstances in mammals.

In mammals, fertilization occurs internally (e.g. cervix, uterotubal junction) and female reproductive tract limits the arrival of sperm to the fertilization site [19]. In mice, 50 million sperms are ejaculated and only 100 to 200 sperm actually reach the site of ovulated oocytes [20], supporting by the observation that in vitro fertilization 
has higher incidence of polyspermy in animals and humans $[16,21,22]$ and the frequency of polyspermic fertilization is directly related to the sperm concentration [23]. However, this mechanism is not completely dependable, and a more stable and long lasting system against polyspermic fertilization is required. The oocyte plasma membrane block to polyspermy has been described in several mammalian species such as humans, mice, and rabbits [24-26]. In some invertebrates, a depolarization of the plasma membrane potential prevents sperm from fusing with the oocytes immediately after fertilization $[27,28]$; however, such an electrical fast block at the level of plasma membrane is not present in mammals. Interestingly, a prior study of in vitro fertilization of bovine oocytes has suggested that the cumulus oophorus also plays a role in blocking polyspermy by engulfing numerous sperm.

In mammals, the primary mechanism in preventing polyspermic fertilization involves biochemical modifications of the surrounding of fertilized oocytes as well as the gamete itself; depending on the species, polyspermy block resides at the zona pellucida, the oolemma, or the perivitelline space $[29,30]$. Generally, the establishment of polyspermy block is initiated and achieved by molecules of cortical granule origin following gamete fusion. Cortical granules are membrane bound secretory organelles located in the cortex of unfertilized oocytes in many invertebrates and vertebrates [31-44]. Mammalian cortical granules, which were first described by C.R. Austin in hamster oocytes using phase contrast microscopy, are derived from Golgi complexes during oocyte growth $[41,45]$. Following fertilization, cortical granules undergo exocytosis to release their contents into the perivitelline space (Figure 1). This secretory process is calcium dependent and is known as the cortical reaction [46-49]. The released cortical granule proteins are responsible for blocking polyspermy by modifying the oocytes' extracellular matrices, such as the zona pellucida in mammals, the vitelline envelope in echinoderms, and the fertilization layers in amphibians [35,42,44,50-55]. Although other biochemical and structural changes in ZP following cortical granule exocytosis are inferred, only the proteolytic cleavage of ZP2 to a form called ZP2f has been experimentally described [56]. This modification of ZP, termed zona reaction or zona hardening, exerts polyspermic block by inhibiting additional sperm to bind ZP and hamper bound sperm to penetrate this ECM [57]. Furthermore, the accumulation of cortical granule components on oolemma and PVS, as well as the fusion of cortical granule membrane with oolemma may play roles in the establishment of a plasma membrane and PVS block to polyspermy by hindering gamete interaction or modifying an incoming sperm $[29,44]$.
Mammalian cortical granules range in size from 0.2 um to 0.6 um in diameter and appear morphologically similar to each other at the ultrastructural level [41,58-60]. Cortical granules are distinct and different from most other regulatory secretory organelles in that they are not renewed once released. These granules are only synthesized in female germ cells and transform an egg upon sperm entry; therefore, this unique organelle has inherent interest for our understanding of the fertilization process. The following review will focus on the biology and dynamics of cortical granules in mammals; topics such as the formation, distribution, pre-fertilization release of cortical granules, molecular mechanisms that regulate granule secretion, granule contents (including biological functions if available), as well as granule population heterogeneity, will be discussed.

\section{Formation, distribution, and pre-fertilization release of cortical granules}

Mammalian cortical granules first appear in the early stages of oocyte growth; however, the exact window of time in which cortical granules are synthesized is different from species to species [41]. In rat and mouse, cortical granules are first seen in the unilaminar follicle [46,61-63], whereas in the human, monkey, hamsters, and rabbit, they first appear in multilayered follicles [46,64-68]. During the early stage of follicular growth, Golgi complexes undergo hypertrophy and proliferation, and the formation of cortical granules from Golgi complexes occurs at this stage $[41,46,69]$. At first, small vesicles are formed from hypertrophied Golgi complexes that migrate toward the subcortical region of the oocytes. These vesicles then coalesce to form mature cortical granules that eventually separate from Golgi complexes [41]. Subcellular structures containing both granules and Golgi complex-like organelles have been observed in growing mouse oocytes [70], and these structures likely represent the sites of cortical granule synthesis. The production of cortical granule in mammalian oocytes is a continuous process, and newly synthesized granules are translocated to the cortex up until the time of ovulation $[41,46,61,65,70-75]$. Several lines of evidence show that the granule migration is a cytoskeleton-dependent process and microfilaments are required for this cortical translocation in both nonmammalian and mammalian animal models, such as sea urchin, porcine, human, and mouse [76-80]. In mammalian oocytes, the migration of cortical granules is an important step in cytoplasmic maturation and has been used routinely as a criterion in assessing the maturity and organelle organization of developing oocytes [81].

Translocated cortical granules are evenly distributed in the cortex of unfertilized oocytes; however, some granules undergo complex changes in distribution prior to 
ovulation [82-84], in results of areas devoid of cortical granules (Figure 2). This meiotic spindle-associated granule-free area was first noted 30 years ago in mouse oocytes, although the extent of this domain apparently was not fully appreciated [46,71]. Recent studies have reported the development of two distinct cortical granule free domains (CGFDs) over the metaphase I and metaphase II spindles in hamster and mouse oocytes, respectively [60,70,82,84-88]. Interestingly, CGFD appears to be unique to rodents since feline, equine, bovine, porcine, and human oocytes lack such a domain [75,89-93]. Several lines of evidence show that redistribution and/or exocytosis of cortical granules during meiotic maturation are likely mechanisms for the formation of CGFDs, supported by the observations of an increase in granule density in the periphery of the CGFD and a decrease in the total number of cortical granules during meiotic maturation $[82,83,85]$. In mice, redistribution of granules appear to be the main factor contributing to development of the first CGFD over metaphase I spindle since cortical granule exocytosis is not evident this time [88] and the formation of this domain is not inhibited in the presence of BAPTA, a $\mathrm{Ca}^{2+}$ chelator that prevents cortical granule exocytosis [87]. However, a study on hamster oocytes reported that small extend of cortical granule release was observed during metaphase I, and both granule migration and exocytosis are claimed to be required for generating first CGFD [82]. The exact mechanisms responsible for the first CGFD formation in rodents may be different from species to species and will need to be determined experimentally. The second CGFD formed over the spindle in metaphase II oocytes is thought largely due to redistribution of cortical granules, supported by the observation of increased granule density at the edge of the granule-containing domain $[87,88]$. Studies in mice also reveal that this cortical granule migration during metaphase I and II transition is chromatin-mediated [87]; however, disruption of the spindle with microtubule inhibitors does not prevent formation of a CGFD over the chromatin [80]. While the formation of both cortical granule free domains appears to occur by granule redistribution, exocytosis has been detected during the metaphase I to metaphase II transition at both light and electron microscopy levels $[82,86,88]$. Interestingly, the pre-fertilization exocytotic event documented during this meiotic transition period does not participate in the second CGFD development and only contributes to the enlargement of the granule-free area since calcium chelator does not abolish the domain formation [87]. Taken together, present findings demonstrate that granule redistribution is the primary mechanism responsible for cortical granule free domain formation in mammals. Changes in cortical granule distribution and formation of CGFDs in mouse oocytes are summarized in Figure 3. Prior study of mouse oocytes reveals that the pre-fertilization exocytosis of cortical granules during metaphase I and II transition involves a specific population of granules [88]. In addition, this exocytotic event takes place during polar body extrusion and only in the
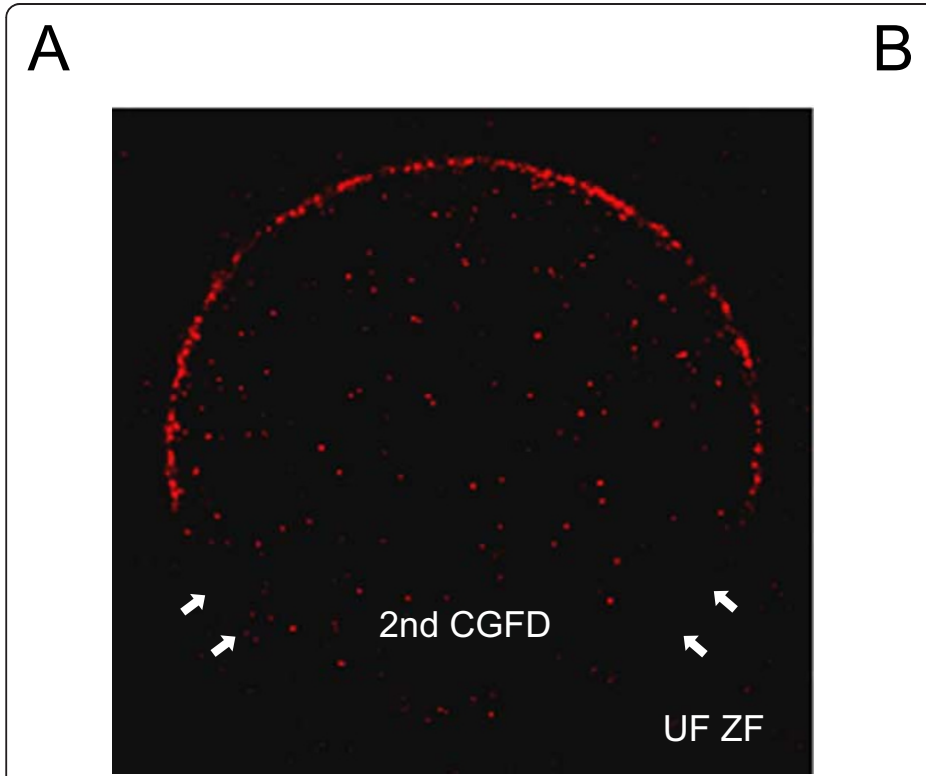

Figure 2 Confocal scanning laser micrographs of cortical granules in mouse oocytes labeled with lectin LCA. (A) An equatorial section of unfertilized zona free oocyte and (B) a three-dimensional projection of unfertilized zona intact oocyte showing the cortical granules (in red), the second cortical granule free domain (arrows), and the pre-fertilization release (arrowhead). 


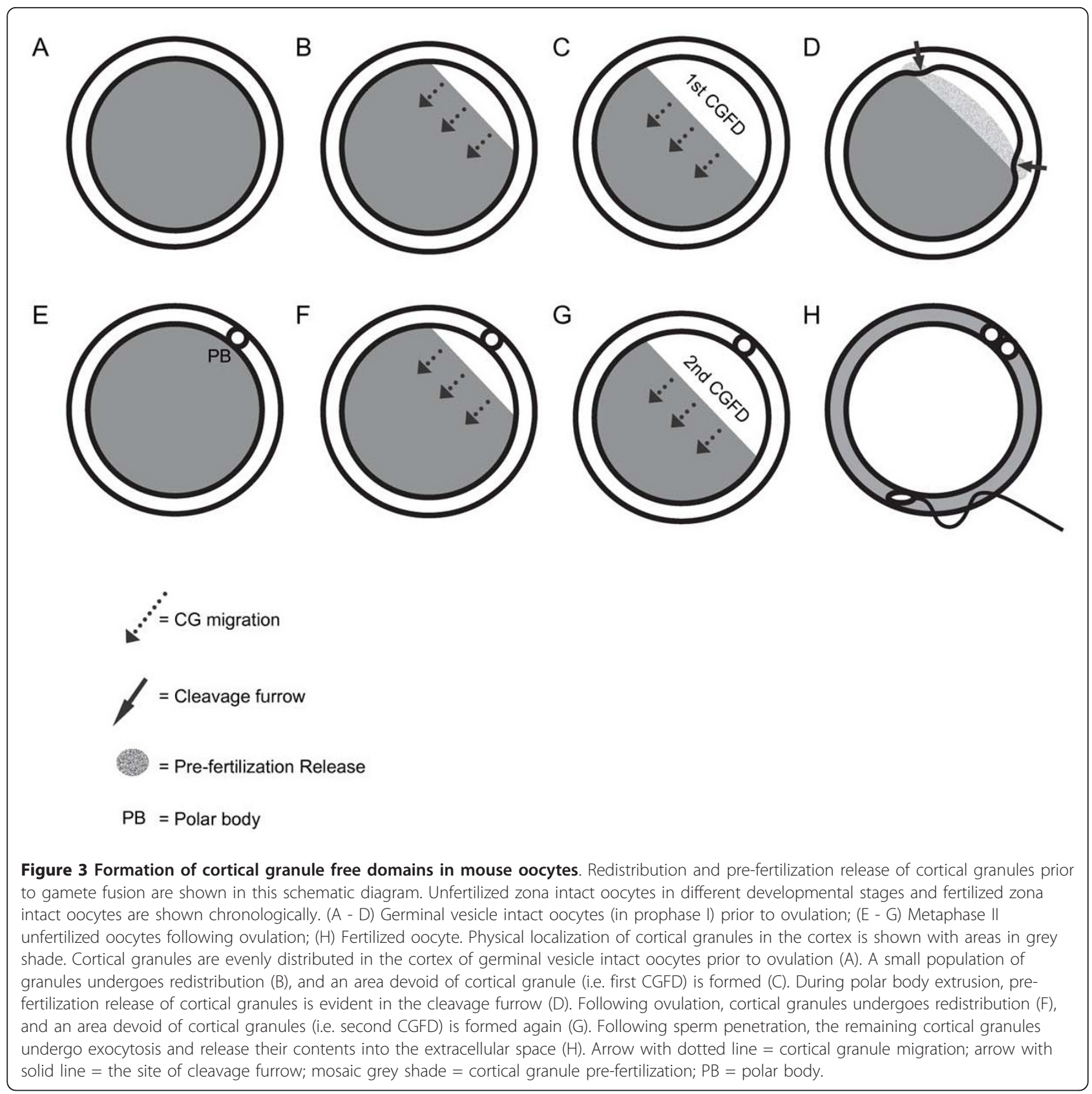

cleavage furrow. The finding is supported by the observation that the mean total numbers of cortical granules per oocyte decreases after polar body extrusion (from $\sim 7400$ to 4100) [85]. Moreover, an electron microscopic study of cortical granules revealed that granules undergoing exocytosis prior to gamete fusion were predominantly confined to an ultrastructurally "light" population [60]. Aside to the pre-fertilization release aforementioned, small populations of cortical granules have been described to undergo exocytosis at different time prior to fertilization. One wave of cortical granules release occurs during metaphase I and has been reported only once in thin sections of hamster oocytes [82]. Another wave of the release, which has only been observed ultrastructurally, takes place after addition of sperm but before sperm penetration when oocytes are inseminated in vitro [60]. However, comparable exocytosis of granules in other mammals has not been described.

Based on the preceding review, we know that pre-fertilization exocytosis of cortical granules, as well as formation of cortical granule free domains, that take place at a specific time and place are well documented in some mammals. Although the exact biological significance and functions of CGFDs and pre-fertilization 
release of cortical granules are elusive, several hypotheses are available. First, the formation of CGFDs ensures that the first and second polar bodies to be extruded with few cortical granules in them; therefore allowing maximum number of cortical granules to exert their biological function(s) at the right window of time. Second, the pre-fertilization release of cortical granules during the metaphase I and II transition may be involved in modification of zona pellucida, perivitelline space, and/ or oolemma directly above the site of the release, thereby minimizing the likelihood for sperm to bind and penetrate oocytes through this area where maternal chromatin is located. Establishment of this local block to sperm entry will reduce the possibility of damaging maternal genetic materials when paternal chromatin undergoes decondensation following gamete fusion. This may be particular importance in rodents in which the oocyte surface area is typically $25 \%$ that of larger mammals and therefore the risk is much higher for sperm entry in this region. This hypothesis is supported by findings showing that sperm-oocyte fusion occurs less frequently in the CGFD $[60,94]$. Lastly, the limited cortical granule exocytosis occurs during oocyte maturation and prior to fertilization may condition the zona by altering the physico-chemical properties slightly in such a way that the zona can be penetrated only by a very "strong" sperm $[82,86]$. This postulation is supported by finding from an early report on the loss of cortical granules and the development of CGFD in oocytes matured in vitro cultures are accompanied by small degree of $\mathrm{ZP} 2$ to ZP2f conversion [83]. In conclusion, most but not all mammalian cortical granules under exocytosis following gamete membrane fusion [41]. Despite the general function of cortical granules in establishing block to polyspermy, it is highly probable that CGFDs and pre-fertilization release perform unique biological function(s) since they occur in a specific location at a specific time. However, the exact physiological functioning of these events still needs to be determined experimentally.

\section{Regulatory mechanisms of cortical granule docking and exocytosis Soluble NSF-attachment protein receptors (SNARE proteins)}

Recently, two classes of proteins, known as $\mathrm{v}$ - and $\mathrm{t}$ SNAREs (soluble NSF-attachment protein receptors), have been demonstrated to play important roles in mediating vesicle docking and membrane fusion. Members of v-SNARE, such as VAMP (vesicle- associated membrane protein) and synaptotagmin, are found on vesicle membranes, while members of t-SNARE, such as syntaxin and SNAP-25 (synaptosome-associated protein of $25 \mathrm{kDa}$ ), are found on target membranes $[95,96]$. Prior to vesicle exocytosis, the v-SNAREs on vesicle membranes, along with another small GTP-binding protein, Rab, bind to appropriate t-SNAREs on target membranes, resulting in docking of vesicles to target membranes. The binding of $v$-SNAREs and t-SNAREs also leads to the formation of a stable protein complex that is necessary for inducing membrane fusion [95-100]. Convincing evidence of interactions between SNARE proteins dictating the exocytosis of cortical granules is presented in several mammalian species. In mice, unfertilized oocytes have been demonstrated to contain the tSNARE protein SNAP-25, which is essential for the cortical reaction since the presence of botulinum neurotoxin A selectively cleaves SNAP-25 and inhibits sperminduced cortical granule exocytosis [101]. A recent work in porcine oocytes reveals that t-SNARE protein SNAP23 and v-SNARE protein VAMP1 are involved in docking cortical granules to the oolemma, and interactions between these SNARE proteins, as well as with the molecule complexin, are responsible for arresting cortical granules in the cortex of the oocytes prior to exocytosis [16]. Additionally, Rab3A, a member of small GTP-binding Rab family, is present in mouse oocytes with a cortical localization in unfertilized oocytes [102]; however, the involvement of Rab3A in cortical granule exocytosis has not been examined. A putative target protein of Rab3A, Rabphilin-3A, is expressed in mouse oocytes, and microinjection of $\mathrm{N}$ - and C-terminal fragment of recombinant Rabphilin 3A inhibits cortical granule exocytosis in a dose-dependent manner, demonstrating that Rabphilin 3A plays a role in mediating cortical reaction in mammalian oocytes [103]. Interaction between SNARE proteins dictating the exocytosis of cortical granules is summarized in Figure 4. Taken together, these observations demonstrate that exocytosis of cortical granules in mammalian oocytes is regulated by a SNARE protein-mediated pathway.

\section{Calcium-dependent pathways}

During oogenesis, cortical granules are translocated to the cortex of unfertilized oocytes and remain positioned several microns below the plasma membrane of the oocytes until stimulated to exocytose. The fusion of sperm plasma membrane with the oolemma, which subsequently activates a series of intracellular signaling pathways, is known to be responsible for the occurrence of cortical reaction [48]. Since calcium ionophore induces cortical granules exocytosis $[75,85,104]$ and the calcium chelator, BAPTA, inhibits this process [47]; elevation of cytosolic calcium is thought to be required for this exocytotic event to take place [46-49]. The complete signal-transducing pathway accountable for cortical granule exocytosis is not yet completely understood. Nevertheless, several studies have revealed that the G 


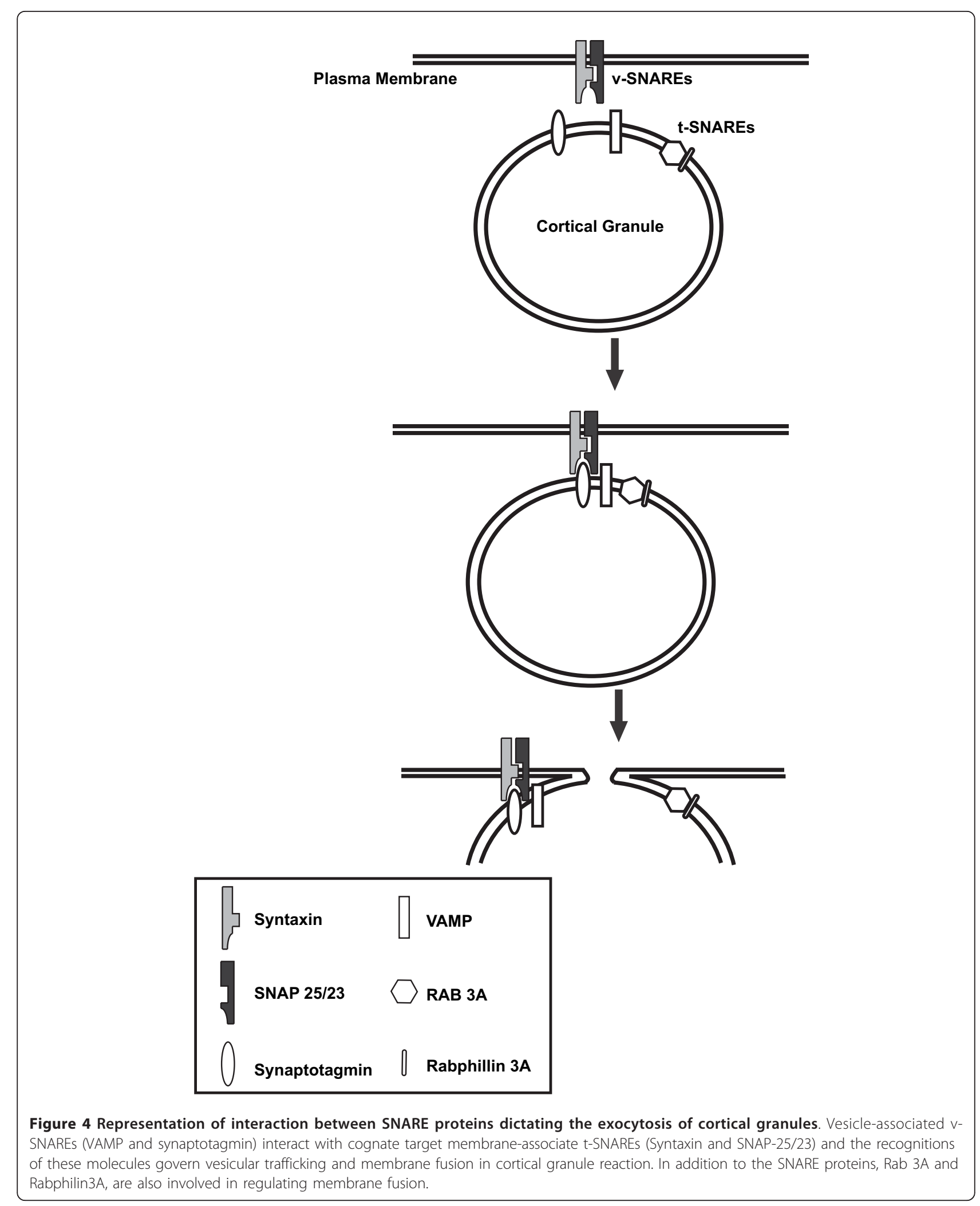


proteins appear to mediate the signal transducing cascade leading to the release of cortical granule contents in mammalian oocytes [105-108]. This conclusion is supported by the observation that microinjection of GTP- $\alpha-S$, a G protein activator, induces cortical reaction in hamsters, sheep, and pig oocytes [105,107]. Furthermore, a $\mathrm{G}$ protein-mediated $\mathrm{PIP}_{2}$ cascade that involves the $\mathrm{IP}_{3}$ production has been implicated in calcium-dependent cortical granule exocytosis. In mammals, a sperm-specific phospholipase $C$ zeta is introduced into the oocyte cytoplasm upon fertilization and participates in the generation of $\operatorname{IP}_{3}[109,110]$. In a study of hamster oocytes, microinjection of $\mathrm{IP}_{3}$ causes intracellular calcium release and induces cortical granule to undergo exocytosis $[105,106]$. Similarly, ZP modification, which is a result of cortical reaction, was reported when $\mathrm{IP}_{3}$ was microinjected into metaphase II mouse oocytes, indicating that $\mathrm{IP}_{3}$ plays a role in a signal transducing cascade that mediates exocytosis of cortical granule [111,112]. Lastly, microinjection of monoclonal antibody $18 \mathrm{~A} 10$, which inhibited $\mathrm{IP}_{3}$-induced calcium release by binding to the $\mathrm{IP}_{3}$ receptor, inhibited $\mathrm{ZP} 2$ to $\mathrm{ZP} 2 \mathrm{f}$ conversion in a dose-dependent manner, indirectly demonstrating inhibition of the cortical reaction [113]. Taken together, these observations support that idea that $\mathrm{IP}_{3}$ is involved in mediating cortical granule exocytosis in mammalian oocytes.

A large body of evidence shows that the other pathway of the $\mathrm{G}$ protein-mediated phosphatidylinositol biphosphate $\left(\mathrm{PIP}_{2}\right)$ cascade, protein kinase $\mathrm{C}(\mathrm{PKC})$ activation by diacylglycerol (DAG), may also function in regulating cortical reaction in mammalian oocytes. A recent study in rats demonstrates that the receptors for activated PKC shuttle activated PKC to the oocyte cortex in order to facilitate cortical reaction [114]. In addition, studies in rat, porcine, mouse, and human oocytes showed that cortical granules were induced to undergo exocytosis when oocytes were treated with PKC activators DAG or phorbol ester [79,112,115-118]. However, the cortical granule exocytosis induced by phorbol esters does not faithfully mimic that seen in fertilized oocytes, and the presence of PKC inhibitors did not result in detectable inhibition of granule release. These findings suggest that PKC alone is not sufficient to stimulate cortical granule to exocytose and the participation of inositol trisphosphate $\left(\mathrm{IP}_{3}\right)$, as well as intracellular free calcium, appears to be necessary in regulating this biological process. Finally, injection of $\mathrm{Ca} 2+/$ calmodulindependent protein kinase (CaMKII) cDNA induces moderate extent of cortical granule exocytosis in mouse oocyte, suggesting CaMKII is also involved in but is not alone capable of inducing cortical reaction. In conclusion, cortical reaction in mammalian oocytes is calciumdependent, and this exocytotic event is mediated by G protein signal-transducing cascade, in which $\mathrm{IP}_{3}$ induces the increase of intracellular calcium. Modulating molecules such as PKC and CaMKII also function in initiating this secretory process.

\section{Cortical granule contents}

The total number of mammalian cortical granule proteins is not known; however, it has been estimated to be between four and fourteen $[56,119,120]$. The amount of cortical granule material available in mammalian oocytes (estimated to be picogram quantities/oocyte) is scanty, which is a major factor that hampers studies on granule constituents. The lack of specific probes to mammalian cortical granules makes the characterization of cortical granules even more difficult. Nevertheless, several molecules have been inferred or demonstrated to be of cortical granule origin. Components identified and characterized in mammalian cortical granules will be described in the following section.

\section{Glycosylated components}

Several studies using polysaccharides-binding dyes or probes reveal that mammalian cortical granules are rich in carbohydrates $[29,46,67,121-128]$. The first cytochemical demonstration of mammalian cortical granules was done using periodic acid Schiff's reagent (PAS), which recognizes polysaccharides [126], to stain paraffin embedded sections of unfertilized hamster oocytes [128]. No cortical granules were detected in the cortex of the fertilized oocytes; however, PAS positive materials, presumably of cortical granule origin, were abundant in the perivitelline space soon after the sperm penetration. Subsequently, hamster and rabbit cortical granules were labeled ultrastructurally with periodic acid with thiocarbohydrazide- $\mathrm{OsO}_{4}$ /silver protein, and phosphotungstic acid, which both bind to sugar residues $[67,127]$. Ruthenium red, a polycationic inorganic dye that can be used in electron microscopy, has also been used to label negatively charged substances such as glycoproteins [123]. The disadvantage of ruthenium red for biological staining is that the dye is not membrane permeable; however, it is useful for stabilizing and demonstrating glycosylated extracellular materials in ultrastructural studies $[29,46,121,122]$. Ultrastructural work on in vivo fertilized rabbit oocytes revealed round masses of intensively stained ruthenium red material that resembled exocytosed cortical granules in crypt-like invaginations of the oolemma [122]. The ruthenium red labeled materials were interpreted to be exocytosed cortical granule contents since they resembled recently released cortical granules and were detected on the surface of fertilized oocytes. An electron microscopic study on in vivo fertilized rat and hamster oocytes also showed ruthenium red stained material freshly exocytosed from 
the cortical granules on the oolemma and in the perivitelline space of the oocytes [46]. Colloidal iron has also been used to localize negatively charged residues such as carbohydrates in electron microscopic studies [124]. In vivo fertilized rabbit oocytes stained with colloidal iron had more negatively charged residues on the oolemma than unfertilized oocytes [125]. This increase in oolemmal staining was interpreted to be due to the release of the cortical granule contents following sperm penetration. Taken together, these observations indicate that mammalian cortical granules contain and are enriched with glycosylated materials.

Lectins are proteins (often of plant origin) that recognize and bind to carbohydrate moieties of glycoconjugates. To date, more than a dozen of lectins have been used cytochemically to demonstrate cortical granules in unfertilized oocytes and/or to localize cortical granule exudates following fertilization $[43,88,93,129]$. The lectins Lens culinaris agglutinin (LCA) and Canavalia ensiformis agglutinin (ConA) that are specific for $\alpha-D$ mannose have been used to label the cortical granules of human, mouse, hamster, cat, and equine oocytes $[25,58,85,88,89,93,130,131]$. In human and mice, LCA binds cortical granules at the light or electron microscopic levels (Figure 2) [25,85,88,131]. Western blots of unfertilized oocytes probed with LCA reveal murine cortical granules contain at least 15 mannosylated proteins [88]. In hamsters, the cortical granules have been shown at both light and electron microscopic levels to bind LCA or ConA $[58,130]$. Lectin blots of unfertilized oocytes show that at least 11 mannosylated proteins are present in hamster cortical granules and that nine of these glycoconjugates may contribute to the formation of cortical granule envelope [130]. In cats, LCA specifically labels cortical granules at both the light microscopic and ultrastructural levels [89]. The lectin peanut agglutinin (PNA) that is specific for $\beta$-D-galactose (especially $\beta$-D-galactose $(1,3)$ - $D$ - $N$-acetylgalactosamine residues) recognizes cortical granules in hamster and pig oocytes [130,132]. Following fertilization, PNA-binding cortical granule components are evident on the oolemma of fertilized hamster oocytes and in the perivitelline space of fertilized pig oocytes. PNA blots of unfertilized hamster oocytes show that at least seven cortical granule glycoconjugates contain $\beta$-D-galactose and of these six are mannosylated since they are also recognized by ConA [130]. Several lectins such as Dolichos biflorus agglutinin (DBA), Ricinus communis agglutinin I ( $\left.\mathrm{RCA}_{120}\right)$, wheat germ agglutinin (WGA), Datura stramonium agglutinin (DSA), Maackia amureusis agglutinin (MAA), Aleuria aurantia agglutinin (AAA), Helix pomatia agglutinin (HPA) that are specific for $\alpha$ D-acetylgalactosamine, galactose, $N$-acetylglucosamine, $N$-acetyllactosamine, $N$-acetylneuraminic acid, fucose, and $\mathrm{D}-\mathrm{N}$-acetylgalactosamine respectively bind cortical granules in hamsters oocytes at light and electron microscopic levels $[129,130]$. The lectin WGA and AAA have been shown cytochemically or at the ultrastructural level to label human cortical granules [133,134]. In addition, lectins that are specific to $N$-acetylgalactosamine (Artocarpus integrifolia, AIA), N-glycolylneuraminic acid (Limax flavus LFA), as well as more complex carbohydrate moieties (Datura stramonium DSA, Maclura pomifera MPA, and Phaseolus vulgaris PHA-E) have been shown to label cortical granules in human oocytes at the electron microscopic level [134]. Finally, the appearance of specific fucosyl and sialyl-rich glycoconjugates, probably of cortical granule origin, in the perivitelline space has been reported in human and mouse oocytes using the lectins Limulus polyphemus agglutinin (LPA), Lotus tetragonolobus agglutinin (FBP), and Ulex europaeus agglutinin (UEA) [135,136]. In conclusion, mammalian cortical granules are rich in carbohydrates, and the carbohydrate moieties on glycosylated constituents are complex.

\section{Proteinases}

Several proteinases have been inferred or demonstrated to be present in mammalian cortical granules [43]. They are thought to be involved in ZP modification and hardening, which result in blocking polyspermy and protecting preimplantation embryos [50,137-139]. The presence of proteinase in mammalian cortical granules was first reported in hamsters [140]. Cortical granule exudate of electrically activated hamster oocytes induced zona modification of unactivated hamster oocytes, which resulted in inhibition of sperm adherence to or penetration through the ZP. A similar inhibitory effect was observed when cortical granule exudate of in vitro fertilized mouse oocytes was used [141]. The presence of trypsin inhibitors such as soybean trypsin inhibitors (SBTI) and p-aminobenzamidine (PAB) alleviated this inhibitory effect. Furthermore, when mouse oocytes were activated by calcium ionophore in the presence of a serine protease inhibitor, leupeptin, the block to polyspermy was not established [142]. A study done by Cherr et al. provided cytochemical evidence for the presence of proteinase in mammalian cortical granules [58]. Fluorescent SBTI bound granules in the cortex of unactivated hamster oocytes and less of this cortical granular labeling by SBTI was observed in activated oocytes. The binding of SBTI to the cortical granules was inhibited when aprotinin and benzamidine hydrochloride were used. Ultrastructurally, biotinylated SBTI recognized by gold-avidin was also shown to bind cortical granules. Interestingly, SBTI bound only the decondensed or the exocytosing cortical granules, but not the condensed granules. It is possible that the activation of this trypsin- 
like proteinase occurs during granule decondensation, which is necessary for the probe binding to the proteinase, or that decondensation of granules is simply necessary to provide physical access for the probe [58]. Taken together, these findings reveal that mammalian cortical granules contain a trypsin-like proteinase and that this cortical granule proteinase functions in blocking polyspermy.

Tissue-type plasminogen activator (tPA), a serine proteinase that converts plasminogen into its active form plasmin, has been inferred to be a mammalian cortical granule component since it is released from oocytes at fertilization or activation when granules undergo exocytosis [143]. The presence of tPA antibody during oocyte activation inhibited the cortical granule-induced zona hardening and block to sperm penetration, suggesting that tPA functions in blocking polyspermy. However, there are observations inconsistent with tPA being a cortical granule protein. First, tPA has not been demonstrated to be present in the cortical granules of unfertilized oocytes at the cytochemical level. Second, primary oocytes do not contain tPA, and the translation of tPA mRNA is only triggered upon resumption of meiotic maturation after most cortical granules have been synthesized $[144,145]$. These findings suggest that tPA is not a cortical granule protein. Nevertheless, it is possible that IPA is secreted from vesicles that are distinct from cortical granules or other vesicles rather than from conventional cortical granules following fertilization or oocyte activation, as shown in recent studies of mouse oocyte calreticulin $[146,147]$. The question of whether mammalian cortical granules contain tPA still needs to be addressed experimentally.

Finally, a proteinase, designated ZP2 proteinase, is released from fertilized and activated oocytes [56]. The proteinase is involved in ZP2 proteolysis, which results in the conversion of ZP2 (120 kDa glycoprotein) to ZP2f (90 kDa glycoprotein), and the enzyme is thought to be responsible for blocking polyspermy [56]. High performance liquid chromatography analysis of oocyte exudate indicates that the ZP2 proteinase has a molecular weight of 21 to $34 \mathrm{kDa}$. The ZP2 proteinase is insensitive to several inhibitors including metallo, carboxyl, sulfhydryl, and serine proteinases inhibitors; however, the ZP2 antibody or the Fab fragment of this antibody inhibits $70 \%$ and $50 \%$ of the enzyme activity respectively.

\section{Ovoperoxidase}

An ovoperoxidase has been detected in cortical granules of unfertilized mouse oocytes using the 3,3'-diaminobenzidine (DAB) cytochemical staining method $[137,148]$. The protein was detected on the plasma membrane, in the perivitelline space, and in the zona pellucida following ionophore activation. The ovoperoxidase staining in activated oocytes could be prevented by its inhibitors phenylhydrazine or sodium sulfite, indicating the labeling is specific. Several lines of evidence suggest that ovoperoxidase catalyzes cross-linking of tyrosines in the zona resulting in hardening of zona pellucida [137]. First, ovoperoxidase inhibitors such as phenylhydrazine, sodium sulfite, sodium azide, and glycine ethyl ester and tyrosine analogs all inhibited zona hardening. Second, the presence of exogenous horseradish peroxidase induced partial hardening of the zona in unfertilized oocytes. Although several studies have demonstrated the presence of peroxidase in cortical granules in invertebrates [149-153], these studies done by Schmell and Gulyas are the only reports of peroxidase in mammalian oocytes $[137,148]$.

\section{Calreticulin}

Calreticulin is a chaperone protein in the endoplasmic reticulum or a lectin involved in chaperoning glycoproteins [154-156]. The protein was inferred to be in hamster cortical granules since immunolabeling with anticalreticulin antibody was located in the cortex of the unfertilized oocytes and appeared to be granular [146]. Oocytes double labeled with the cortical granule specific lectin LCA and calreticulin antibody showed co-localization of the two probes in many granules, indicating the presence of calreticulin in cortical granules. Calreticulin can be detected on western blots of the oocyte's activation medium demonstrating the protein was exocytosed in response to oocyte activation. The authors of this study proposed that calreticulin may function as a chaperone for other exocytosed cortical granule components that function in blocking polyspermy. They also suggested calreticulin acts as a lectin that binds and blocks the carbohydrate moieties of glycoproteins important for oocyte-sperm interaction, thereby blocking polyspermy. However, more experimental data are required to support these postulates. A recent study using mice has demonstrated that calreticulin is released by vesicles in the cortex other than cortical granules since mouse oocytes double labeled with cortical granule specific lectin LCA and calreticulin specific antibody did not show co-localization of two probes [147]. Following its release, calreticulin was shown to be present on the extracellular surface of the oocyte's plasma membrane and in the perivitelline space, and the protein was demonstrated to interact with the cytoskeleton of the oocyte and mediate transmembrane signaling that leads to cell cycle resumption [147]. The discrepancy in findings of two studies and the exact origin of calreticulin need to be resolved experimentally.

\section{$\mathrm{N}$-Acetylglucosaminidase}

$\mathrm{N}$-acetylglucosaminidase, a glycosidase that has high specificity for terminal $\mathrm{N}$-acetylglucosamine residues, 
was localized in mouse cortical granules at the immunoelectron microscopy level [157]. The enzyme activity was detected in oocytes exudates following artificial activation. The $\mathrm{N}$-acetylglucosaminidase found in mouse cortical granules has maximal activity at $\mathrm{pH} 4.5$ to 5.5 and was identified as the $\beta$-hexosaminidase $B$ isoform ( $\beta, \beta$ homodimer). Oocytes activated in the present of $\mathrm{N}$-acetylglucosaminidase inhibitor or antibodies showed a significant increase in the number of sperm binding to the zona when oocytes were fertilized in vitro [157]. This result indicates that $N$-acetylglucosaminidase is required for the mouse zona block to polyspermy, which removes the terminal $\mathrm{N}$-acetylglucosamine residues on zona pellucida to abolish sperm binding $[157,158]$. Although $\mathrm{N}$-acetylglucosaminidase is also found in the cortical granules of Xenopus oocytes, it is not known if this enzyme is present in oocytes of other mammals.

\section{p32}

p32 is a mouse cortical granule component recognized specifically by the monoclonal antibody $3 \mathrm{E} 10$, which was made against calcium ionophore-induced oocyte exudates [119], and the protein has a molecular weight of 32 $\mathrm{kDa}$ on western blots. In metaphase II oocytes, the $3 \mathrm{E} 10$ antibody stained granules in the cortex, and no labeling was observed in the region over the spindle. Oocytes double labeled with 3E10 and LCA, which specifically labels mouse cortical granules [85], exhibited a nearly complete co-localization, demonstrating the presence of the 3E10 antigen in mouse cortical granules. In fertilized oocytes and two-cell embryos, a very small amount of p32 remained on the oocyte or embryo surfaces. The presence of p32 could not be detected in eight-cell embryos, morulae, or blastocysts. p32 appears not to play a role in blocking polyspermy since the 3E10 antibody did not interfere with the ability of fertilized oocytes to establish such block. Interestingly, 3E10 staining was significantly reduced or almost undetectable in fertilized oocytes. This observation suggests that the released p 32 is only functionally active during the early period of fertilization or the protein undergoes conformational change following its release from the cortical granules so that the 3E10 epitope is no longer available.

\section{Peptidylarginine deiminase (PAD/ABL 2 antigen/p75)}

p75 is a mouse cortical granule component recognized specifically by the polyclonal antibody $\mathrm{ABL}_{2}$, which was made against zona free whole mouse blastocysts [120]. The protein has a molecular weight of $75 \mathrm{kDa}$, and twodimensional gel electrophoresis of mouse oocytes revealed that p75 exists as four isoforms with isoelectric points between 4.9 and 5.3. The protein was localized to mouse cortical granules at the immunoelectron microscopy level, and it was released following in vitro fertilization [120]. The synthesis of p75 was first detected in $<20 \mu \mathrm{m}$ oocytes and continued to increase to about $1.5 \%$ of total protein synthesis during oocyte growth [159]. In metaphase II oocytes, p75 synthesis decreased about 10-fold. Synthesis of p75 was observed following in vitro translation of germinal vesicle intact oocyte poly $(\mathrm{A})^{+}$RNA, but not of metaphase II oocyte poly(A) ${ }^{+}$RNA indicating that $\mathrm{p} 75$ synthesis is under translational regulation during oocyte growth and maturation. To identify this cortical granule protein, Liu et al. immuneprecipitated p75 from mouse ovarian lysate and the protein was sequence by tandem mass spectrometry. Based on a partial amino acid sequence, p75 was identified to be peptidylarginine deiminase (PAD) [160]. This study is the first report on biochemical identification of mammalian cortical granule component based on protein sequence. Interestingly, PAD appears to be a non-glycosylated secretory protein and plays a regulatory role after its release at fertilization in embryonic cleavage and early preimplantation development. In a study of hamster cortical granules, the $\mathrm{ABL}_{2}$ antibody was shown to recognize two cortical granule proteins designated p62 and p56, which have molecular weights on western blots of 62 and $56 \mathrm{kDa}$, respectively [161]. Following fertilization, both hamster cortical granule proteins were released and contributed to the formation of the cortical granule envelope, an extracellular matrix in the perivitelline space of fertilized mammalian oocytes following cortical reaction [121,161,162]. An in vivo functional study showed that p62 and p56 did not appear to be involved in blocking polyspermy since fertilization remained monospermic in all oocytes when treated in vivo with the $\mathrm{ABL}_{2}$ antibody. Furthermore, in vivotreatment of 2-cell hamster embryos with the antibody inhibited cleavage and delayed blastocyst formation in a dose-dependent manner, in consist with the observation that the mouse PAD of cortical granule origin functions in preimplantation development. Interestingly, cortical granule proteins, p62 and p56, in hamster appeared to be immunologically related to the sea urchin cortical granule protein hyalin since they were recognized by the antibody IL2 that was made against purified S. purpuratus hyalin [163]. The conclusion is further supported by the finding that IL2 antibody inhibited hamster 2-cell embryos cleavage in vivo. However, the exact molecular identities of these $\mathrm{ABL}_{2}$ binidng cortical granule proteins in hamster oocytes still need to be determined. Taken together, PAD is present in mouse cortical granules and plays a regulatory role in preimplantation development. It will be interesting to examine whether PAD is also present in oocytes of other rodent species and the antibody $\mathrm{ABL}_{2}$ reacts and recognizes proteins of cortical granule origin in other mammals. 


\section{Cortical granule populations}

Different types of cortical granules have been described in unfertilized oocytes of some species such as fish, amphibians, crustaceans, echinoderms, and mammals [34,37-40,58,60,74,164-167]. In the next section, works focused on granule population in non-mammalian species will be presented first, followed by studies in mammals, to provide a more fundamental understanding and broader perspective on cortical granule heterogeneity.

In the Zebrafish, Brachydanio rerio, two types of cortical granules, the dark type (electron-dense) and the light type (electron-lucent), have been identified at the electron microscopy level [38]. Differential cytochemical staining with either Alcian blue or toluidine blue also confirms the presence of these two types of cortical granules in unfertilized oocytes of Zebrafish [38]. The killifish, Fundulus heteroclitus, has two populations of cortical granules; at the ultrastructural level, one population contains filamentous and/or granular material, while the other does not [39]. In the frog, Xenopus laevis, two types of cortical granules are differentially distributed in unfertilized oocytes [34]. One type has a homogeneous matrix of moderate electron density and is located in the animal hemisphere, while the other type has a loose flocculent material and is located in the vegetal hemisphere [34]. In the horseshoe crab, Limulus polyphemus L., two types of cortical granules have been described, one appears to be electron-translucent and the other to be electron-dense [37]. In lobsters, Homarus americanus and $H$ gammarus, four types of cortical granules, that are distinguishable based on their ultrastructural appearance, are present in the cortex of ovarian oocytes and are referred to as high-density, lowdensity, moderately dense, and ring cortical granules. The contents of each type of granule are released in sequence from the cortex of the oocyte into the perivitelline space following fertilization [40]. In the sea urchin, Strongylocentrotus purpuratus, the presence of biochemically distinct populations of cortical granules has been shown based on the immunocytochemical observations. One population of cortical granules contains an antigen recognized by two specific antibodies, $1 \mathrm{G} 8$ and $\mathrm{B} 2 \mathrm{C} 2$, while the other population does not [164]. In another species of the sea urchin, Lytechinus variagatus, four types of granules have been identified immunocytochemically in the unfertilized oocytes [165]. These granules ultimately migrate to the cortex and sequentially release their contents into the perivitelline space upon fertilization.

Mammalian cortical granules are generally similar in morphology $[46,58,67,168,169]$ although dark and light granules have been reported based on their ultrastructural appearance $[58,60,74,166,167]$. Unlike some species such as fish, amphibians, crustaceans, echinoderms, heterogeneity of cortical granules in mammals is well documented but poorly understood. In humans, two populations of cortical granules of which one has a homogeneous electron-dense core and the other has granular or fluffy contents are present in unfertilized oocytes [166,167]. In pig, hamster, and mouse oocytes, dark and light forms of cortical granules have also been described based on their electron density $[58,60,74]$. It is not known if this difference in electron density represents different stages in granule maturation, different types of granules, or different stages in exocytosis $[58,60,170]$. Not till recently, biochemically distinct populations of cortical granules are demonstrated cytochemically in unfertilized mouse oocytes. By taking advantage of two probes specific to mammalian cortical granules, lectin LCA (mannosyl glycoconjugate-binding) and the $\mathrm{ABL}_{2}$ antibody (PAD protein-binding), two populations of cortical granules, of which one contains PAD and the other lacks of this molecule, are shown to be present in unfertilized oocytes [88]. However, whether the heterogeneity in granule populations corresponds to different biological functioning is still a question needs to be answered.

\section{Concluding remarks}

To date, only several partially characterized molecules have been reported to be of cortical granule origin in mammals. Cortical granules of invertebrates (e.g. sea urchins and starfish) and some vertebrates (e.g. fish and frogs) are better studied as these model animals served rich source for experimentation, due to the ease in oocyte isolation and manipulation. Our understanding of mammalian cortical granule biochemistry and biogenesis has been hampered for several reasons. First, characterization of granule components is a laborious task due to the paucity of mammalian cortical granule material available per oocyte and low number of oocytes retrievable per animal. It is estimated that each oocyte (i.e. in mice) contains $\sim 20 \mathrm{ng}$ of total proteins and only $2.5 \%$ to $5 \%$ of these proteins are from cortical granules [119]. Second, the lack of specific probes for mammalian cortical granules makes analytical tests difficult to perform. Studies of cortical granules in humans can be even more troublesome since experimental samples are mostly obtained from volunteer donors, who undergo reproductive assistant treatments, and the number and quality of oocytes collected cannot always be optimal. Although non-mammalian animals serve as excellent models and provide research basis for mammalian species, one should keep in mind that direct extrapolation of information between mammalian and other animal modes requires caution because cellular and molecular 
differences among different species can affect the experimental outcome.

From the preceding review, we know that mammalian cortical granules are secretory organelles, which are stimulated to undergo calcium dependent and SNARE protein-mediated exocytosis upon gamete fusion, in result of a block to polyspermy. Evolved and extended from the historical viewpoint, mammalian cortical granules are more complex and have more functions than previously realized. Biochemical heterogeneity and complex redistribution of granule in the cortex of unfertilized oocytes prior to ovulation are documented. A small population of granules is evident to exocytose prior to sperm penetration; a number of granule components are reported to function following fertilization in regulating embryonic cleavage and preimplantation development. In addition to providing biological basis to better understand reproduction process, new findings of mammalian cortical granules have made scientists to start apprehending their clinical relevance. Biological parameters of cortical granules, such as granule synthesis and translation to the cortex, are used routinely as criterion to determine the developmental stage of human oocyte grown in vivo or in vitro. Timely release of these granules is essential for a successful fertilization to occur, especially for individuals who are reproductively challenged and require artificial assistance. Interestingly, low fertilization rate was observed following cryopreservation of mouse oocytes and this low rate was attributed to cryopreservant-induced premature cortical granule discharge $[171,172]$. Previous study of the cortical granules in unfertilized human oocytes from failed IVF trials also showed a significant decrease in number of granules, suggesting that premature release of cortical granules and early establishment of block to polyspermy prior to insemination may be the cause for some unsuccessful cases of in vitro fertilization [173].

Cortical granules are first identified in sea urchins by Harvey in 1910 [174], inspired by Derbès' observation of the fertilization envelope 150 years ago. Not till four decades later, mammalian cortical granules were documented in hamster oocytes by Austin [45]. Fifty five years of time is full of excitement as we have witnessed many technological breakthroughs in reproductive biology and fascinating scientific discoveries of mammalian cortical granules. However, this unique organelle is far from being fully appreciated and a broader perspective on its biochemistry and functional role(s) should be developed and presented. On the quest to find answers to these questions we encounter in studies of mammalian cortical granules, continuous efforts made by scientists in the field of reproductive biology should led us a step closer to better understanding the nature of cortical granules and embracing the beauty of this organelle.

\section{List of abbreviations used}

AAA: Aleuria aurantia agglutinin; AIA: Artocarpus integrifolia; CaMKII: Ca2 +/calmodulin-dependent protein kinase; CGFDs: cortical granule free domains; ConA: Canavalia ensiformis agglutinin; DAB: 3,3'-diaminobenzidine; DAG: diacylglycerol; DBA: Dolichos biflorus agglutinin; DSA: Datura stramonium; DSA: Datura stramonium agglutinin (DSA); ECM: extracellular matrix; FBP: Lotus tetragonolobus agglutinin; HPA: Helix pomatia agglutinin; $\mathrm{IP}_{3}$ : Inositol trisphosphate; LCA: Lens culinaris agglutinin; LFA: Limax flavus; LPA: Limulus polyphemus agglutinin; MAA: Maackia amureusis agglutinin; MPA: Maclura pomifer; PAB: p-aminobenzamidine; PAD: peptidylarginine deiminase; PAS: periodic acid Schiff's reagent; PHA-E: Phaseolus vulgaris; $\mathrm{PIP}_{2}$ phosphatidylinositol biphosphate; PKC: protein kinase C; PNA: peanut agglutinin; PVS: perivitelline space; RCA 120 : Ricinus communis agglutinin I; SBTI: soybean trypsin inhibitors; SNAP: synaptosome-associated protein; SNARE: soluble NSF-attachment protein receptors; tPA: tissue-type plasminōgen activatör; UEA: Ulex europaéus agglutinin; VAMP: vesicleassociated membrane protein; WGA: wheat germ agglutinin; ZP: zona pellucida.

\section{Acknowledgements}

The author gratefully acknowledges the National Science Council of Republic of China for their support of the work presented here.

\section{Competing interests}

The authors declare that they have no competing interests.

Received: 29 August 2011 Accepted: 17 November 2011 Published: 17 November 2011

\section{References}

1. Bleil JD, Wassarman PM: Structure and function of the zona pellucida: identification and characterization of the proteins of the mouse oocyte's zona pellucida. Dev Biol 1980, 76(1):185-202.

2. Boja ES, Hoodbhoy T, Fales HM, Dean J: Structural characterization of native mouse zona pellucida proteins using mass spectrometry. J Biol Chem 2003, 278(36):34189-34202.

3. Yudin Al, Cherr GN, Katz DF: Structure of the cumulus matrix and zona pellucida in the golden hamster: a new view of sperm interaction with oocyte-associated extracellular matrices. Cell Tissue Res 1988, 251(3):555-564.

4. Lin Y, Mahan K, Lathrop WF, Myles DG, Primakoff P: A hyaluronidase activity of the sperm plasma membrane protein $\mathrm{PH}-20$ enables sperm to penetrate the cumulus cell layer surrounding the egg. J Cell Biol 1994, 125(5):1157-1163.

5. Florman HM, Wassarman PM: O-linked oligosaccharides of mouse egg ZP3 account for its sperm receptor activity. Cell 1985, 41(1):313-324.

6. Wassarman PM, Litscher ES: Towards the molecular basis of sperm and egg interaction during mammalian fertilization. Cells Tissues Organs 2001, 168:(1-2):36-45.

7. Morales P, Cross NL, Overstreet JW, Hanson FW: Acrosome intact and acrosome-reacted human sperm can initiate binding to the zona pellucida. Dev Biol 1989, 133(2):385-392.

8. Gahlay G, Gauthier L, Baibakov B, Epifano O, Dean J: Gamete recognition in mice depends on the cleavage status of an egg's zona pellucida protein. Science 329(5988):216-219.

9. Eto K, Huet C, Tarui T, Kupriyanov S, Liu HZ, Puzon-McLaughlin W, Zhang XP, Sheppard D, Engvall E, Takada Y: Functional classification of ADAMs based on a conserved motif for binding to integrin alpha 9beta 1: implications for sperm-egg binding and other cell interactions. J Biol Chem 2002, 277(20):17804-17810.

10. Almeida EA, Huovila AP, Sutherland AE, Stephens LE, Calarco PG, Shaw LM, Mercurio AM, Sonnenberg A, Primakoff P, Myles DG, et al: Mouse egg integrin alpha 6 beta 1 functions as a sperm receptor. Cell 1995, 81(7):1095-1104

11. Evans JP: Sperm disintegrins, egg integrins, and other cell adhesion molecules of mammalian gamete plasma membrane interactions. Front Biosci 1999, 4:D114-131.

12. Cuasnicu PS, Ellerman DA, Cohen DJ, Busso D, Morgenfeld MM, Da Ros VG: Molecular mechanisms involved in mammalian gamete fusion. Arch Med Res 2001, 32(6):614-618. 
13. Chen MS, Tung KS, Coonrod SA, Takahashi Y, Bigler D, Chang A Yamashita Y, Kincade PW, Herr JC, White JM: Role of the integrinassociated protein CD9 in binding between sperm ADAM 2 and the egg integrin alpha6beta1: implications for murine fertilization. Proc Natl Acad Sci USA 1999, 96(21):11830-11835.

14. Chen H, Sampson NS: Mediation of sperm-egg fusion: evidence that mouse egg alpha6beta1 integrin is the receptor for sperm fertilinbeta. Chem Biol 1999, 6(1):1-10.

15. Zhu X, Evans JP: Analysis of the roles of RGD-binding integrins, alpha(4)/ alpha(9) integrins, alpha(6) integrins, and CD9 in the interaction of the fertilin beta (ADAM2) disintegrin domain with the mouse egg membrane. Biol Reprod 2002, 66(4):1193-1202.

16. Tsai PS, van Haeften T, Gadella BM: Preparation of the cortical reaction: maturation-dependent migration of SNARE proteins, clathrin, and complexin to the porcine oocyte's surface blocks membrane traffic until fertilization. Biol Reprod 2011, 84(2):327-335.

17. Xia P, Wang Z, Yang Z, Tan J, Qin P: Ultrastructural study of polyspermy during early embryo development in pigs, observed by scanning electron microscope and transmission electron microscope. Cell Tissue Res 2001, 303(2):271-275

18. Han YM, Wang WH, Abeydeera LR, Petersen AL, Kim JH, Murphy C, Day BN, Prather RS: Pronuclear location before the first cell division determines ploidy of polyspermic pig embryos. Biol Reprod 1999, 61(5):1340-1346.

19. Braden AW: Distribution of sperms in the genital tract of the female rabbit after coitus. Aust J Biol Sci 1953, 6(4):693-705.

20. Wassarman PM: Gamete interactions during mammalian fertilization. Theriogenology 1994, 41:31-44.

21. VanDerVen HH, Al-Hasani S, Diedrich K, Hamerich U, Lehmann F, Krebs D: Polyspermy in in vitro fertilization of human oocytes: frequency and possible causes. Ann N Y Acad Sci 1985, 442:88-95.

22. Wentz AC, Repp JE, Maxson WS, Pittaway DE, Torbit CA: The problem of polyspermy in in vitro fertilization. Fertil Steril 1983, 40(6):748-754.

23. Wolf DP, Byrd W, Dandekar P, Quigley MM: Sperm concentration and the fertilization of human eggs in vitro. Biol Reprod 1984, 31(4):837-848.

24. Horvath PM, Kellom T, Caulfield J, Boldt J: Mechanistic studies of the plasma membrane block to polyspermy in mouse eggs. Mol Reprod Dev 1993, 34(1):65-72.

25. Sengoku K, Tamate K, Takaoka Y, Horikawa M, Goishi K, Okada R, Tsuchiya K, Ishikawa M: Requirement of sperm-oocyte plasma membrane fusion for establishment of the plasma membrane block to polyspermy in human pronuclear oocytes. Mol Reprod Dev 1999, 52(2):183-188.

26. Overstreet JW, Bedford JM: Comparison of the penetrability of the egg vestments in follicular oocytes, unfertilized and fertilized ova of the rabbit. Dev Biol 1974, 41(1):185-192.

27. Jaffe LA: Fast block to polyspermy in sea urchin eggs is electrically mediated. Nature 1976, 261(5555):68-71.

28. Whitaker MJ, Steinhardt RA: Evidence in support of the hypothesis of an electrically mediated fast block to polyspermy in sea urchin eggs. Dev Biol 1983, 95(1):244-248.

29. Dandekar $P$, Talbot $P$ : Perivitelline space of mammalian oocytes: extracellular matrix of unfertilized oocytes and formation of a cortical granule envelope following fertilization. Mol Reprod Dev 1992, 31(2):135-143.

30. Yanagimachi R: Mammalian Fertilization. In The Physiology of Reproduction. Edited by: Knobil E, Neill JD. New York: Raven Press; 1994:189-317.

31. Runnstrom J: The vitelline membrane and cortical particles in sea urchin eggs and their function in maturation and fertilization. Adv Morphog 1966, 5:221-325

32. Wischnitzer S: The ultrastructure of the cytoplasm of the developing amphibian egg. Adv Morphog 1966, 5:131-179.

33. Hebard CN, Herold RC: The ultrastructure of the cortical cytoplasm in the unfertilized egg and first cleavage zygote of Xenopus laevis. Exp Cell Res 1967, 46(3):553-570.

34. Grey RD, Wolf DP, Hedrick JL: Formation and structure of the fertilization envelope in Xenopus laevis. Dev Biol 1974, 36(1):44-61.

35. Schuel $\mathrm{H}$ : Secretory functions of egg cortical granules in fertilization and development. Gamete Res 1978, 1:299-382.

36. Holland ND: Electron microscopic study of the cortical reaction in eggs of the starfish (Patria miniata). Cell Tissue Res 1980, 205(1):67-76.
37. Bannon GA, Brown GG: Vesicle involvement in the egg cortical reaction of the horseshoe crab, Limulus polyphemus L. Dev Biol 1980, 76(2):418-427.

38. Hart NH, Yu SF: Cortical granule exocytosis and cell surface reorganization in eggs of Brachydanio. J Exp Zool 1980, 213(1):137-159.

39. Brummett AR, Dumont JN: Cortical vesicle breakdown in fertilized eggs of Fundulus heteroclitus. J Exp Zool 1981, 216(1):63-79.

40. Talbot P, Goudeau M: A complex cortical reaction leads to formation of the fertilization envelope in the lobster, Homarus. Gamete Res 1988, 19(1):1-18.

41. Gulyas BJ: Cortical granules of mammalian eggs. Int Rev Cytol 1979, 63:357-392.

42. Cran DG, Esper CR: Cortical granules and the cortical reaction in mammals. J Reprod Fertil Supp/ 1990, 42:177-188.

43. Hoodbhoy T, Talbot P: Mammalian cortical granules: contents, fate, and function. Mol Reprod Dev 1994, 39(4):439-448.

44. Sun QY: Cellular and molecular mechanisms leading to cortical reaction and polyspermy block in mammalian eggs. Microsc Res Tech 2003, 61(4):342-348.

45. Austin CR: The cortical granules of hamster eggs. Expt Cell Res 1956, 10:533-540.

46. Szollosi D: Development of cortical granules and the cortical reaction in rat and hamster eggs. Anat Rec 1967, 159(4):431-446.

47. Kline D, Kline JT: Repetitive calcium transients and the role of calcium in exocytosis and cell cycle activation in the mouse egg. Dev Biol 1992, 149(1):80-89.

48. Ducibella T: The cortical reaction and development of activation competence in mammalian oocytes. Hum Reprod Update 1996, 2(1):29-42.

49. Abbott AL, Ducibella T: Calcium and the control of mammalian cortical granule exocytosis. Front Biosci 2001, 6:D792-806.

50. Cherr GN, Ducibella T: Activation of the mammalian egg: cortical granule distribution, exocytosis, and the block to polyspermy. In Fertilization in Mammals. Edited by: Bavister BD, Cummins ERS, Roldan. Norwell, MA: Serono Symposis; 1990:309-334.

51. Grey RD, Working PK, Hedrick JL: Evidence that the fertilization envelope blocks sperm entry in eggs of Xenopus laevis: interaction of sperm with isolated envelopes. Dev Biol 1976, 54(1):52-60.

52. Chandler DE, Heuser J: The vitelline layer of the sea urchin egg and its modification during fertilization. A freeze-fracture study using quickfreezing and deep-etching. J Cell Biol 1980, 84(3):618-632.

53. Weidman PJ, Kay ES, Shapiro BM: Assembly of the sea urchin fertilization membrane: isolation of proteoliaisin, a calcium-dependent ovoperoxidase binding protein. J Cell Biol 1985, 100(3):938-946.

54. Larabell C, Chandler DE: Fertilization-induced changes in the vitelline envelope of echinoderm and amphibian eggs: self-assembly of an extracellular matrix. J Electron Microsc Tech 1991, 17(3):294-318.

55. Hedrick $J \mathrm{~L}$, Nishihara T: Structure and function of the extracellular matrix of anuran eggs. J Electron Microsc Tech 1991, 17(3):319-335.

56. Moller CC, Wassarman PM: Characterization of a proteinase that cleaves zona pellucida glycoprotein ZP2 following activation of mouse eggs. Dev Biol 1989, 132:103-112.

57. Austin $C R$, Braden AWH: Early reaction of the rodent eggy to spermatozoon penetration. J Exp Biol 1956, 33:358-365.

58. Cherr GN, Drobnis EZ, Katz DF: Localization of cortical granule constituents before and after exocytosis in the hamster egg. J Exp Zool 1988, 246(1):81-93.

59. Cran DG: Cortical granules during oocyte maturation and fertilization. J Reprod Fertil Suppl 1989, 38:49-62.

60. Nicosia SV, Wolf DP, Inoue M: Cortical granule distribution and cell surface characteristics in mouse eggs. Dev Biol 1977, 57(1):56-74

61. Szollosi D: Oocyte maturation and paternal contribution to the embryo in mammals. Curr Top Pathol 1976, 62:9-27.

62. Odor DL, Blandau RJ: Ultrastructural studies on fetal and early postnatal mouse ovaries. II. Cytodifferentiation. Am J Anat 1969, 125(2):177-215.

63. Kang $\mathrm{YH}$ : Development of the zona pellucida in the rat oocyte. Am J Anat 1974, 139(4):535-565.

64. Hope J: The fine structure of the developing follicle of the rhesus ovary. J Ultrastruct Res 1965, 12(5):592-610.

65. Baca M, Zamboni L: The fine structure of human follicular oocytes. $J$ Ultrastruct Res 1967, 19(3):354-381. 
66. Zamboni L: Fine morphology of the follicle wall and follicle cell-oocyte association. Biol Reprod 1974, 10(2):125-149.

67. Selman K, Anderson E: The formation and cytochemical characterization of cortical granules in ovarian oocytes of the golden hamster (Mesocricetus auratus). J Morphol 1975, 147(3):251-274.

68. Krauskopf C: [Electron microscopic studies of the structure of the oocyte and the 2-cell stage in the rabbit. I. Oocyte]. Z Zellforsch Mikrosk Anat 1968, 92(2):275-295.

69. Guraya SS: Recent progress in the structure, origin, composition and function of cortical granules in animal eggs. Int Rev Cytol 1982, 78:257-360.

70. Ducibella T, Duffy P, Buetow J: Quantification and localization of cortical granules during oogenesis in the mouse. Biol Reprod 1994, 50(3):467-473.

71. Zamboni L: Ultrastructure of mammalian oocytes and ova. Biol Reprod 1970, 2(Suppl 2):44-63.

72. Sathananthan AH, Trounson AO: Ultrastructural observations on cortical granules in human follicular oocytes cultured in vitro. Gamete Res 1982, 5:191-198.

73. Sathananthan AH, Trounson AO: Ultrastructure of cortical granule release and zona interaction in monospermic and polyspermic ova fertilized in virtro. Gamete Res 1982, 6:225-234.

74. Cran DG, Cheng WT-K: Changes in cortical granules during porcine oocyte maturation. Gamete Res 1985, 11:311-319.

75. Wang WH, Sun QY, Hosoe M, Shioya Y, Day BN: Quantified analysis of cortical granule distribution and exocytosis of porcine oocytes during meiotic maturation and activation. Biol Reprod 1997, 56(6):1376-1382.

76. Kim NH, Day BN, Lee HT, Chung KS: Microfilament assembly and cortical granule distribution during maturation, parthenogenetic activation and fertilisation in the porcine oocyte. Zygote 1996, 4(2):145-149.

77. Liu S, Li Y, Feng HL, Yan JH, Li M, Ma SY, Chen ZJ: Dynamic modulation of cytoskeleton during in vitro maturation in human oocytes. Am J Obstet Gynecol 203(2):151, e151-157.

78. Wessel GM, Conner SD, Berg L: Cortical granule translocation is microfilament mediated and linked to meiotic maturation in the sea urchin oocyte. Development 2002, 129(18):4315-4325.

79. Sun QY, Lai L, Park KW, Kuhholzer B, Prather RS, Schatten H: Dynamic events are differently mediated by microfilaments, microtubules, and mitogen-activated protein kinase during porcine oocyte maturation and fertilization in vitro. Biol Reprod 2001, 64(3):879-889.

80. Connors SA, Kanatsu-Shinohara M, Schultz RM, Kopf GS: Involvement of the cytoskeleton in the movement of cortical granules during oocyte maturation, and cortical granule anchoring in mouse eggs. Dev Biol 1998, 200(1):103-115.

81. Damiani P, Fissore RA, Cibelli JB, Long CR, Balise JJ, Robl JM, Duby RT: Evaluation of developmental competence, nuclear and ooplasmic maturation of calf oocytes. Mol Reprod Dev 1996, 45(4):521-534.

82. Okada A, Yanagimachi R, Yanagimachi H: Development of a cortical granule-free area of cortex and the perivitelline space in the hamster oocyte during maturation and following ovulation. J Submicrosc Cytol 1986, 18(2):233-247.

83. Ducibella T, Kurasawa S, Rangarajan S, Kopf GS, Schultz RM: Precocious loss of cortical granules during mouse oocyte meiotic maturation and correlation with an egg-induced modification of the zona pellucida. Dev Biol 1990, 137(1):46-55.

84. Ducibella T, Duffy P, Reindollar R, Su B: Changes in the distribution of mouse oocyte cortical granules and ability to undergo the cortical reaction during gonadotropin-stimulated meiotic maturation and aging in vivo. Biol Reprod 1990, 43(5):870-876.

85. Ducibella T, Anderson E, Albertini DF, Aalberg J, Rangarajan S: Quantitative studies of changes in cortical granule number and distribution in the mouse oocyte during meitoic maturation. Devel Biol 1988, 130:184-197.

86. Okada A, Inomata K, Nagae T: Spontaneous cortical granule release and alteration of zona pellucida properties during and after meiotic maturation of mouse oocytes. Anat Rec 1993, 237(4):518-526.

87. Deng M, Kishikawa H, Yanagimachi R, Kopf GS, Schultz RM, Williams CJ: Chromatin-mediated cortical granule redistribution is responsible for the formation of the cortical granule-free domain in mouse eggs. Dev Biol 2003, 257(1):166-176.

88. Liu M, Sims D, Calarco P, Talbot P: Biochemical heterogeneity, migration, and pre-fertilization release of mouse oocyte cortical granules. Reprod Biol Endocrinol 2003, 1(77).
89. Byers AP, Barone MA, Donoghue AM, Wildt DE: Mature domestic cat oocyte does not express a cortical granule-free domain. Biol Reprod 1992, 47(5):709-715.

90. Long CR, Damiani P, Pinto-Correia C, MacLean RA, Duby RT, Robl JM: Morphology and subsequent development in culture of bovine oocytes matured in vitro under various conditions of fertilization. J Reprod Fertil 1994, 102(2):361-369

91. Santella L, Alikani M, Talansky BE, Cohen J, Dale B: Is the human oocyte plasma membrane polarized? Hum Reprod 1992, 7(7):999-1003.

92. Lodde V, Modina S, Maddox-Hyttel P, Franciosi F, Lauria A, Luciano AM: Oocyte morphology and transcriptional silencing in relation to chromatin remodeling during the final phases of bovine oocyte growth. Mol Reprod Dev 2008, 75(5):915-924.

93. Carneiro GF, Liu IK, Hyde D, Anderson GB, Lorenzo PL, Ball BA: Quantification and distribution of equine oocyte cortical granules during meiotic maturation and after activation. Mol Reprod Dev 2002, 63(4):451-458.

94. Johnson MH, Eager D, Muggleton-Harris A, Grave HM: Mosaicism in organisation concanavalin A receptors on surface membrane of mouse egg. Nature 1975, 257(5524):321-322.

95. Fasshauer D, Eliason WK, Brunger AT, Jahn R: Identification of a minimal core of the synaptic SNARE complex sufficient for reversible assembly and disassembly. Biochemistry 1998, 37(29):10354-10362.

96. Weber T, Zemelman BV, McNew JA, Westermann B, Gmachl M, Parlati F, Sollner TH, Rothman JE: SNAREpins: minimal machinery for membrane fusion. Cell 1998, 92(6):759-772.

97. Jahn R, Grubmuller H: Membrane fusion. Curr Opin Cell Biol 2002, 14(4):488-495.

98. Jahn R, Lang T, Sudhof TC: Membrane fusion. Cell 2003, 112(4):519-533.

99. Jahn R, Hanson PI: Membrane fusion. SNAREs line up in new environment. Nature 1998, 393(6680):14-15.

100. Jahn R, Sudhof TC: Membrane fusion and exocytosis. Annu Rev Biochem 1999, 68:863-911.

101. Ikebuchi Y, Masumoto N, Matsuoka T, Yokoi T, Tahara M, Tasaka K, Miyake A, Murata Y: SNAP-25 is essential for cortical granule exocytosis in mouse eggs. Am J Physiol 1998, 274(6 Pt 1):C1496-1500.

102. Masumoto N, Ikebuchi Y, Tahara M, Yokoi T, Tasaka K, Miyake A, Murata Y: Expression of Rab3A in the cortical region in mouse metaphase II eggs. J Exp Zool 1998, 280(1):91-96

103. Masumoto N, Sasaki T, Tahara M, Mammoto A, lkebuchi Y, Tasaka K, Tokunaga M, Takai Y, Miyake A: Involvement of Rabphilin-3A in cortical granule exocytosis in mouse eggs. J Cell Biol 1996, 135 (6 Pt 2):1741-1747.

104. Steinhardt RA, Epel D, Carroll EJ, Yanagimachi R: Is calcium ionophore a universal activator for unfertilized oocytes? Nature (London) 1974, 252:41-43.

105. Cran DG, Moor RM, Irvine RF: Initiation of the cortical reaction in hamster and sheep oocytes in response to inositol trisphosphate. J Cell Sci 1988, 91(Pt 1):139-144

106. Miyazaki S: Inositol 1,4,5-trisphosphate-induced calcium release and guanine nucleotide-binding protein-mediated periodic calcium rises in golden hamster eggs. J Cell Biol 1988, 106(2):345-353.

107. Machaty Z, Mayes MA, Prather RS: Parthenogenetic activation of porcine oocytes with guanosine-5'-O-(3'-thiotriphosphate). Biol Reprod 1995, 52(4):753-758.

108. Kim JH, Machaty Z, Cabot RA, Han YM, Do HJ, Prather RS: Development of pig oocytes activated by stimulation of an exogenous $\mathrm{G}$ protein-coupled receptor. Biol Reprod 1998, 59(3):655-660.

109. Swann $\mathrm{K}$, Yu Y: The dynamics of calcium oscillations that activate mammalian eggs. Int J Dev Biol 2008, 52(5-6):585-594.

110. Miyazaki S, Shirakawa H, Nakada K, Honda Y: Essential role of the inositol 1,4,5-trisphosphate receptor/Ca2+ release channel in $\mathrm{Ca} 2+$ waves and Ca2+ oscillations at fertilization of mammalian eggs. Dev Biol 1993, 158(1):62-78.

111. Kurasawa S, Schultz RM, Kopf GS: Egg-induced modifications of the zona pellucida of mouse eggs: effects of microinjected inositol 1,4,5trisphosphate. Dev Biol 1989, 133(1):295-304.

112. Ducibella T, Kurasawa S, Duffy P, Kopf GS, Schultz RM: Regulation of the polyspermy block in the mouse egg: maturation-dependent differences in cortical granule exocytosis and zona pellucida modifications induced by inositol 1,4,5-trisphosphate and an activator of protein kinase C. Biol Reprod 1993, 48(6):1251-1257. 
113. Xu Z, Kopf GS, Schultz RM: Involvement of inositol 1,4,5-trisphosphatemediated Ca2+ release in early and late events of mouse egg activation. Development 1994, 120(7):1851-1859.

114. Haberman Y, Alon LT, Eliyahu E, Shalgi R: Receptor for activated C kinase (RACK) and protein kinase $C(P K C)$ in egg activation. Theriogenology 75(1):80-89.

115. Sun QY, Wang WH, Hosoe M, Taniguchi T, Chen DY, Shioya Y: Activation of protein kinase $\mathrm{C}$ induces cortical granule exocytosis in a $\mathrm{Ca}(2$ + )-independent manner, but not the resumption of cell cycle in porcine eggs. Dev Growth Differ 1997, 39(4):523-529.

116. Jones KT: Protein kinase $C$ action at fertilization: overstated or undervalued? Rev Reprod 1998, 3(1):7-12.

117. Raz T, Ben-Yosef D, Shalgi R: Segregation of the pathways leading to cortical reaction and cell cycle activation in the rat egg. Biol Reprod 1998, 58(1):94-102.

118. Wu XQ, Zhang X, Li XH, Cheng HH, Kuai YR, Wang S, Guo YL: Translocation of classical PKC and cortical granule exocytosis of human oocyte in germinal vesicle and metaphase II stage. Acta Pharmacol Sin 2006, 27(10):1353-1358.

119. Gross VS, Wessel G, Florman HM, Ducibella T: A Monoclonal Antibody That Recognizes Mammalian Cortical Granules and a32-Kilodalton Protein in Mouse Eggs. Biol Reprod 2000, 63(2):575-581.

120. Pierce KE, Siebert MC, Kopf GS, Schultz RM, Calarco PG: Characterization and localization of a mouse egg cortical granule antigen prior to and following fertilization or egg activation. Dev Biol 1990, 141(2):381-392.

121. Dandekar $P$, Mate $K E$, Talbot P: Perivitelline space of marsupial oocytes: extracellular matrix of the unfertilized oocyte and formation of a cortical granule envelope following the cortical reaction. Mol Reprod Dev 1995, 41(3):368-373.

122. Gordon $M$, Fraser LR, Dandekar PV: The effect of ruthenium red and concanavalin $A$ on the vitelline surface of fertilized and unfertilized rabbit ova. Anat Rec 1975, 181:95-112.

123. Luft JH: Ruthenium red and violet. I. Chemistry, purification, methods of use for electron microscopy and mechanism of action. Anat Rec 1971, 171(3):347-368.

124. Gasic GJ, Berwick L, Sorrentino M: Positive and negative colloidal iron as cell surface electron stains. Lab Invest 1968, 18(1):63-71.

125. Cooper GW, Bedford JM: Charge density change in the vitelline surface following fertilization of the rabbit egg. J Reprod Fertil 1971, 25(3):431-436

126. Gomori G: The periodic-acid Schiff stain. Am J Clin Pathol 1952, 22(3):277-281.

127. Flechon JE: Nature glycoproteique des granules corticaux de l'oeuf lapine. Mise en evidence par l'utilisation comparee de techniques cytochimiques ultrastructurales. J Microsc 1970, 9:221-242.

128. Yanagimachi $R$, Chang MC: Fertilizable life of golden hamster ova and their morphological changes at the time of losing fertilizability. J Exp Zool 1961, 148:185-204.

129. El-Mestrah M, Kan FW: Distribution of lectin-binding glycosidic residues in the hamster follicular oocytes and their modifications in the zona pellucida after ovulation. Mol Reprod Dev 2001, 60(4):517-534.

130. Hoodbhoy T, Talbot P: Characterization, fate, and function of hamster cortical granule components. Mol Reprod Dev 2001, 58(2):223-235.

131. Ghetler Y, Raz T, Ben Nun I, Shalgi R: Cortical granules reaction after intracytoplasmic sperm injection. Mol Hum Reprod 1998, 4(3):289-294.

132. Yoshida M, Cran DG, Pursel VG: Confocal and fluorescence microscopic study using lectins of the distribution of cortical granules during the maturation and fertilization of pig oocytes. Mol Reprod Dev 1993, 36(4):462-468.

133. Talevi R, Gualtieri R, Tartaglione G, Fortunato A: Heterogeneity of the zona pellucida carbohydrate distribution in human oocytes failing to fertilize in vitro. Hum Reprod 1997, 12(12):2773-2780.

134. Jimenez-Movilla M, Aviles M, Gomez-Torres MJ, Fernandez-Colom PJ, Castells MT, de Juan J, Romeu A, Ballesta J: Carbohydrate analysis of the zona pellucida and cortical granules of human oocytes by means of ultrastructural cytochemistry. Hum Reprod 2004, 19(8):1842-1855.

135. Tam PPL, Loong EPL, Chiu TTY: Localization of fucosyl glycoproteins in human oocytes following insemination for in vitro fertilziation. J In Vitro Fertil Embryo Transfer 1990, 7:141-145.

136. Lee SH, Ahuja KK, Gilburt DJ, Whittingham DG: The appearance of glycoconjugates associated with cortical granule release during mouse fertilization. Development 1988, 102(3):595-604.
137. Schmell ED, Gulyas BJ: Ovoperoxidase activity in ionophore treated mouse eggs. II. Evidence for the enzyme's role in hardening the zona pellucida. Gam Res 1980, 3:279-290.

138. Gwatkin RBL: Fertilization Mechanisms in Man and Mammals. New York: Plenum Press; 1977.

139. Dunbar BS: Morphological, biochemical, and immunochemical characterization of the mammalian zona pellucida. In Mechanism and Control of Animal Fertilization. Edited by: Harmann JF. New York: Academic Press; 1983:140-175.

140. Gwatkin RBL, Williams DT, Hartmann JF, Kniazuk M: The zona reaction of hamster and mouse eggs:production in vitro by a trypsin-like protease from cortical granules. J Reprod Fertil 1973, 32:259-265.

141. Wolf DP, Hamada M: Induction of zonal and egg plasma membrane blocks to sperm penetration in mouse eggs with cortical granule exudate. Biol Reprod 1977, 17(3):350-354.

142. Tawia SA, Lopata A: The fertilization and development of mouse oocytes following cortical granule discharge in the presence of a protease inhibitor. Hum Reprod 1992, 7(7):1004-1009.

143. Zhang X, Rutledge J, Khamsi F, Armstrong DT: Release of tissue-type plasminogen activator by activated rat eggs and its possible role in the zona reaction. Mol Reprod Dev 1992, 32(1):28-32.

144. Huarte J, Belin D, Vassali JD: Plasminogen activator in mouse and rat oocytes: induction during meiotic maturation. Cell 1985, 43:551-558.

145. Bicsak TA, Cajander SB, Peng XR, Ny T, LaPolt PS, Lu JK, Kristensen P, Tsafriri A, Hsueh AJ: Tissue-type plasminogen activator in rat oocytes: expression during the periovulatory period, after fertilization, and during follicular atresia [published erratum appears in Endocrinology 1990 May;126(5):2434]. Endocrinology 1989, 124(1):187-194.

146. Munoz-Gotera RJ, Hernandez-Gonzalez EO, Mendoza-Hernandez G, Contreras RG, Mujica A: Exocytosis of a $60 \mathrm{kDa}$ protein (calreticulin) from activated hamster oocytes. Mol Reprod Dev 2001, 60(3):405-413.

147. Tutuncu L, Stein P, Ord TS, Jorgez CJ, Williams CJ: Calreticulin on the mouse egg surface mediates transmembrane signaling linked to cell cycle resumption. Dev Biol 2004, 270(1):246-260.

148. Gulyas BJ, Schmell ED: Ovoperoxidase activity in ionophore treated mouse eggs. I. Electron microscopic localization. Gam Res 1980, 3:267-277

149. Katsura S, Tominaga A: Peroxidatic activity of catalase in the cortical granules of sea urchin eggs. Dev Biol 1974, 40(2):292-297.

150. Foerder CA, Shapiro BM: Release of ovoperoxidase from the sea urchin eggs hardens the fertilizxation membrane with tyrosine crosslinks. Proc Natl Acad Sci 1977, 79:4214-4218.

151. Hall HG: Hardening of the sea urchin fertilization envelope by peroxidecatalysed phenolic coupling of tyrosines. Cell 1978, 15:343-355.

152. LaFleur GJ Jr, Horiuchi Y, Wessel GM: Sea urchin ovoperoxidase: oocytespecific member of a heme-dependent peroxidase superfamily that functions in the block to polyspermy. Mech Dev 1998, 70(1-2):77-89.

153. Roels F: Peroxidatic activity in Artemia salina oocytes: role in eggenvelope hardening. Exp Cell Res 1971, 69(2):452-456.

154. Michalak M, Mariani P, Opas M: Calreticulin, a multifunctional Ca2+ binding chaperone of the endoplasmic reticulum. Biochem Cell Biol 1998, 76(5):779-785

155. White TK, Zhu Q, Tanzer ML: Cell surface calreticulin is a putative mannoside lectin which triggers mouse melanoma cell spreading. J Biol Chem 1995, 270(27):15926-15929.

156. Spiro RG, Zhu Q, Bhoyroo V, Soling HD: Definition of the lectin-like properties of the molecular chaperone, calreticulin, and demonstration of its copurification with endomannosidase from rat liver Golgi. J Biol Chem 1996, 271(19):11588-11594.

157. Miller DJ, Gong X, Decker G, Shur BD: Egg cortical granule Nacetylglucosaminidase is required for the mouse zona block to polyspermy. J Cell Biol 1993, 123(6):1431-1440.

158. Miller DJ, Macek MB, Shur BD: Complementarity between sperm surface beta-1,4-galactosyltransferase and egg-coat ZP3 mediates sperm-egg binding. Nature 1992, 357(6379):589-593.

159. Pierce KE, Grunvald EL, Schultz RM, Kopf GS: Temporal pattern of synthesis of the mouse cortical granule protein, p75, during oocyte growth and maturation. Dev Biol 1992, 152(1):145-151.

160. Liu M, Oh A, Calarco P, Yamada M, Coonrod SA, Talbot P: Peptidylarginine deiminase (PAD) is a mouse cortical granule protein that plays a role in 
preimplantation embryonic development. Reprod Biol Endocrinol 2005, 3:42.

161. Hoodbhoy T, Dandekar P, Calarco P, Talbot P: p62/p56 are cortical granule proteins that contribute to formation of the cortical granule envelope and play a role in mammalian preimplantation development. Mol Reprod Dev 2001, 59(1):78-89.

162. Talbot P, DiCarlantonio G: The oocyte-cumulus complex: ultrastructure of the extracellular components in hamsters and mice. Gam Res 1984, 10:127-142.

163. Hoodbhoy T, Carroll EJ, Talbot P: Relationship Between p62 and p56, Two Proteins of the Mammalian Cortical Granule Envelope, and Hyalin, the Major Component of the Echinoderm Hyaline Layer. Biol Reprod 2000, 62:979-987.

164. Anstrom JA, Chin JE, Leaf DS, Parks AL, Raff RA: Immunocytochemical evidence suggesting heterogeneity in the population of sea urchin egg cortical granules. Dev Biol 1988, 125(1):1-7.

165. Matese JC, Black S, McClay DR: Regulated exocytosis and sequential construction of the extracellular matrix surrounding the sea urchin zygote. Dev Biol 1997, 186(1):16-26.

166. Rousseau P, Meda P, Lecart C, Haumont S, Ferin J: Cortical granule release in human follicular oocytes. Biol Reprod 1977, 16(1):104-111.

167. Hinduja IN, Kumar A, Anand Kumar TC: Ultrastructure of the cortex in the human egg. Hum Reprod 1990, 5(1):66-70.

168. Gulyas BJ: Cortical granules in artifically activated (parthenogenetic) rabbit eggs. Am J Anat 1974, 140(4):577-582.

169. Gulyas BJ: Ultrastructural observations on rabbit, hamster and mouse eggs following electrical stimulation in vitro. Am J Anat 1976, 147(2):203-218.

170. Raz T, Skutelsky E, Amihai D, Hammel I, Shalgi R: Mechanisms leading to cortical reaction in the mammalian egg. Mol Reprod Dev 1998, 51(3):295-303.

171. Schalkoff ME, Oskowitz SP, Powers RD: Ultrastructural observations of human and mouse oocytes treated with cryopreservatives. Biol Reprod 1989, 40(2):379-393.

172. Vincent C, Pickering SJ, Johnson MH: The hardening effect of dimethylsulphoxide on the mouse zona pellucida requires the presence of an oocyte and is associated with a reduction in the number of cortical granules present. J Reprod Fertil 1990, 89(1):253-259.

173. Ducibella T, Dubey A, Gross V, Emmi A, Penzias AS, Layman L, Reindollar R: A zona biochemical change and spontaneous cortical granule loss in eggs that fail to fertilize in in vitro fertilization. Fertil Steril 1995, 64(6):1154-1161.

174. Harvey EN: The mechanism of membrane formation and other early changes in developing sea urchins' eggs as bearing on the problem of artificial parthenogenesis. J Exp Zool 1910, 8(4):355-376.

doi:10.1186/1477-7827-9-149

Cite this article as: Liu: The biology and dynamics of mammalian cortical granules. Reproductive Biology and Endocrinology 2011 9:149. 